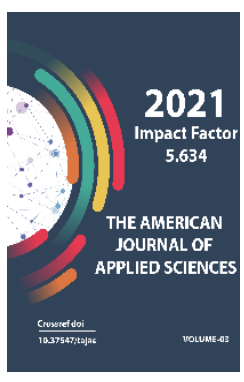

Journal Website: http://usajournalshub.c om/index,php/tajas

Copyright: Original content from this work may be used under the terms of the creative commons attributes 4.0 licence.

\section{Change Of Cotton Fiber Quality Indicators Under Technological Processes}

\author{
Mirjamol Mirkarimovich Mirxojaev \\ Doctor Of Philosophy (PhD), Department Of Metrology, Standardization And Quality \\ Management, Namangan Institute Of Engineering And Technology, Republic Of Uzbekistan \\ Dilmuhammad Davronbek Ogli Atambayev \\ Assistant, Department Of Metrology, Standardization And Quality Management, Namangan \\ Institute Of Engineering And Technology, Republic Of Uzbekistan \\ Ismoiljon Isroiljon Ogli Lutfillaev \\ 3rd Year Student, Department Of Metrology, Standardization And Quality Management, \\ Namangan Institute Of Engineering And Technology, Republic Of Uzbekistan

\section{Jamshidbek Maripjon Ogli Jurayev} \\ 3rd Year Student, Department Of Metrology, Standardization And Quality Management, \\ Namangan Institute Of Engineering And Technology, Republic Of Uzbekistan
}

\title{
ABSTRACT
}

In this article, the quality indicators of fiber under the influence of various technological processes of Sultan selection cotton were determined and the optimal variant of the technological process for production was recommended.

Basic expressions tangled fiber, cortical fiber, knot, staple mass length, specific tensile strength, fiber maturity.

\section{KEYWORDS}

Flagella, skin with fiber, nodules, staple mass length, relative breaking load, fiber maturity.

\section{INTRODUCTION}

Cotton entering the primary processing plant consists of impurities and mineral defects. Pollution includes flowers, leaves, twigs, stones, sand, etc. [1].

The amount of contamination is divided into large and small defects. If the size of the defects is greater than $8 \mathrm{~mm}$, they are considered large defects. These impurities are located on the surface and inner layers of the seed cotton, as well as have adhesive strength with different fibers. If there are impurities on 
the surface of the seed cotton, the adhesion strength to the fiber will be low [1].

The effectiveness of cleaning cotton from impurities depends on selection variety, moisture, variety, fiber length, the nature of impurities and other indicators [2-4].

The amount of contaminants in the cotton is cleaned using ginning equipment at ginneries. The impact efficiency of the cleaning equipment workpieces, in turn, depends on several factors, namely the cleaning efficiency, the speed of movement of the workpieces, the design of the workpieces, the repetition of cleaning and the degree of airflow cleaning [5].

Moisture is very important during cotton cleaning. This is because the more moisture there is, the more difficult it is to separate the defects, leading to an increase in the number of seeds that are hit or injured. Therefore, the moisture content of cotton received at ginneries and ginning plants should not exceed $11 \%$ for grade I and $13 \%$ for sub-varieties. If the moisture content of the gin equipment is in the range of $7-8 \%$, the quality of cotton fiber is maintained [6-7].

Cotton with high moisture content has a large amount of defects and waste, the cleaning rate of cotton is low, leading to a deterioration in fiber quality. As a result, the quality of the finished product obtained from the fiber will be negatively affected. In addition, the cotton gets stuck between the working parts of the machine, and the seeds that are hit or injured cause an increase in the amount of fibrous fiber in the shell [8].

During the initial processing of cotton, the amount of defects and waste in the composition of cotton fiber increases under the influence of high humidity and technological processes above the standard requirements. If the moisture content of the seed cotton is higher than the standard values, the amount of fiber, complex twisted fiber, contaminants in the fiber content will increase, and the amount of husk fiber, beaten or injured seeds will decrease. In addition, the more technological processes the seed cotton undergoes, the better it is to be cleaned of contaminants, leading to an increase in the amount of some beaten or injured seeds, tangled and complex tangled fiber, husk fiber. At the same time, due to the low moisture content leads to an increase in the total amount of waste and waste in the composition of cotton fiber due to an increase in the amount of bark fibers and nodules, beaten or injured seeds. In addition, some selection varieties have a low degree of purification and do not meet the demand. It follows that not all varieties created may meet the demand [9].

Defects and wastes in cotton fiber were determined in different technological process sequences, and the test results are given in Table 1.

One of the main quality indicators of cotton fiber is the change in the composition of the defect and the amount of waste under the influence of moisture. When the amount of defects and waste in the composition of cotton fiber is higher than the standard values, the quality of the fiber deteriorates, and the physical and mechanical properties of the yarn obtained from it are negatively affected. According to the state standard, cotton fiber is divided into a number of classes, that is, higher, good, medium, dirty and bad, depending on the amount of pollution, and the price varies according to these classes [1]. 
The American Journal of Applied sciences

The impact of different selection varieties of cotton on technological processes, which are initially processed in ginneries, varies. While some selection varieties are well cleaned of contaminants, some are the opposite. Therefore, it is necessary to create optimal conditions for each variety grown in our country. In addition, the seeds of some selection varieties are brittle, and there is a possibility of injury under the influence of technological processes [2].

Defects in cotton fiber and changes in the amount of waste in the sequence of different technological processes

Table 1.

\begin{tabular}{|c|c|c|c|c|}
\hline \multirow[t]{2}{*}{$\mathrm{T} / \mathrm{p}$} & \multirow[t]{2}{*}{ Defect in fiber content and amount of waste,\% } & \multicolumn{3}{|c|}{ Options } \\
\hline & & 1 & 2 & 3 \\
\hline \multicolumn{5}{|c|}{ Before the technological process } \\
\hline 1. & Common shortcomings & 2,80 & 3,00 & 2,51 \\
\hline 2. & A handful of uncooked fiber & 0,14 & 0,16 & 0,12 \\
\hline 3. & Fiddly fiber & - & - & - \\
\hline 4. & Complex tangled fiber & - & - & - \\
\hline 5. & Shell fiber & 0,34 & 0,38 & 0,28 \\
\hline 6. & Beaten or injured seeds & 0,50 & 0,54 & 0,43 \\
\hline 7. & Knots & 0,10 & 0,08 & 0,08 \\
\hline 8. & Dirt & 1,62 & 1,84 & 1,50 \\
\hline \multicolumn{5}{|c|}{ After the technological process } \\
\hline 1. & Common shortcomings & 2,42 & 2,60 & 2,00 \\
\hline 2. & A handful of uncooked fiber & 0,12 & 0,15 & 0,11 \\
\hline 3. & Fiddly fiber & - & 0,02 & - \\
\hline 4. & Complex tangled fiber & - & - & - \\
\hline 5. & Shell fiber & 0,74 & 0,69 & 0,60 \\
\hline 6. & Beaten or injured seeds & 0,62 & 0,72 & 0,50 \\
\hline 7. & Knots & 0,20 & 0,18 & 0,12 \\
\hline 8. & Dirt & 0,74 & 0,84 & 0,67 \\
\hline
\end{tabular}


The results of the study showed that compared to the fiber obtained before the technological process sequence in Option 1, the total amount of defect or waste in the fiber obtained after the technological process sequence decreased by $13.6 \%$, the amount of cortical fiber $54.1 \%$, the amount of crushed or injured seeds increased by $19.4 \%$, the number of nodules increased by $50.0 \%$, the amount of contaminants decreased by $54.3 \%$, compared to the fiber obtained before the sequence of the technological process in option 2 Thus, after the sequence of the technological process, the total amount of defects or waste in the fiber content decreased by $13.3 \%$, the amount of cortical fiber by $44.9 \%$, the amount of crushed or injured seeds by $25.0 \%$, the amount of knots by $55.6 \%$. contaminants, the amount of impurities decreased by $54.3 \%$, compared with the performance of the fiber obtained before the sequence of the technological process in option 3, the technological the total amount of defect or waste in the fiber content obtained after the sequence of the process decreased by $20.3 \%$, the amount of cortical fiber increased by
$53.3 \%$, the amount of crushed or injured seeds increased by $14.0 \%$, the amount of nodules increased by $33.3 \%$, impurities the amount decreased by $53.3 \%$.

The high performance and quality of sewing products are inextricably linked with the body and back yarns in the fabric that make it up. One of the main indicators of raw materials textile fabrics in the production of garments is the hardness or softness of the fabric. Applying the abrasion resistance of a garment to a part of the fabric knowing the virginity level of the fabric will result in a longer shelf life and an increase in the quality index [10].

Quality indicators of suit fabrics with different fiber content increase the chances of producing a quality product if the fibers in the study are used for the products studied [11].

Based on the results of the study, histograms of changes in fiber properties under the influence of technological processes were constructed in Figures 1-3

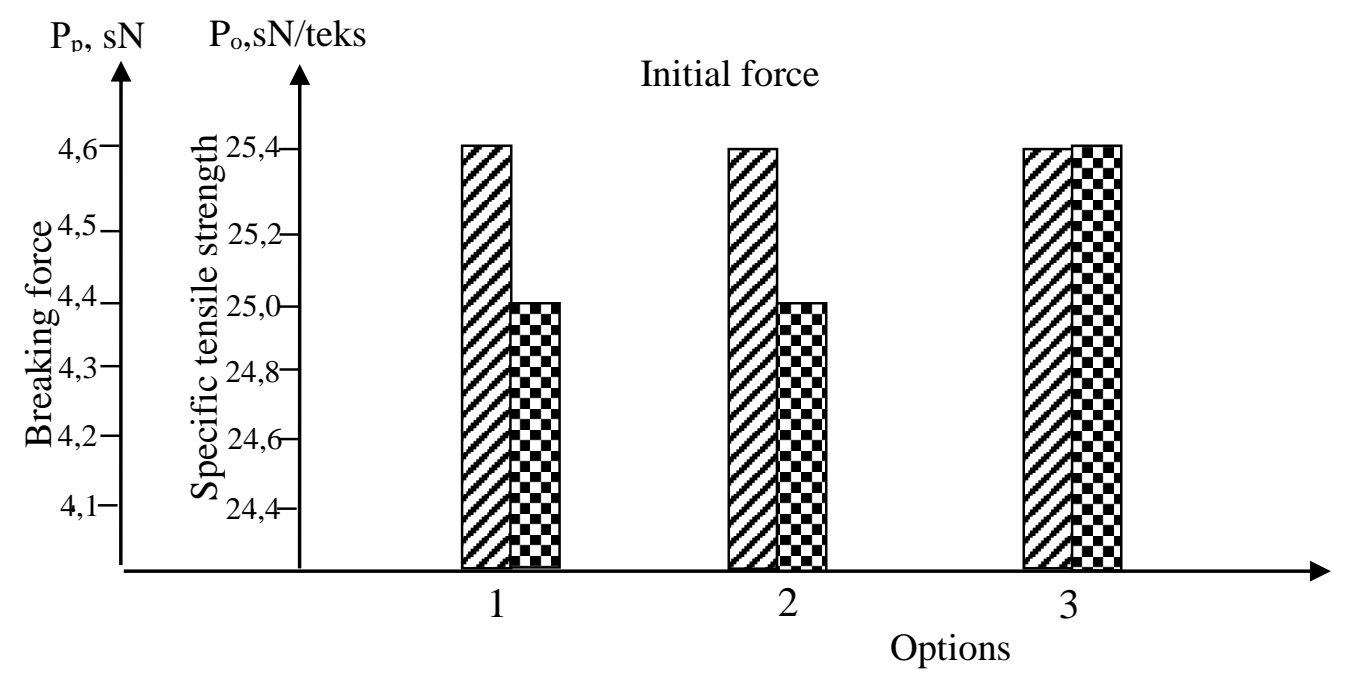

Figure 1. Influence of technological processes on fiber tensile strength and specific tensile strength.

घ- breaking force;

- -specific tensile strength. 


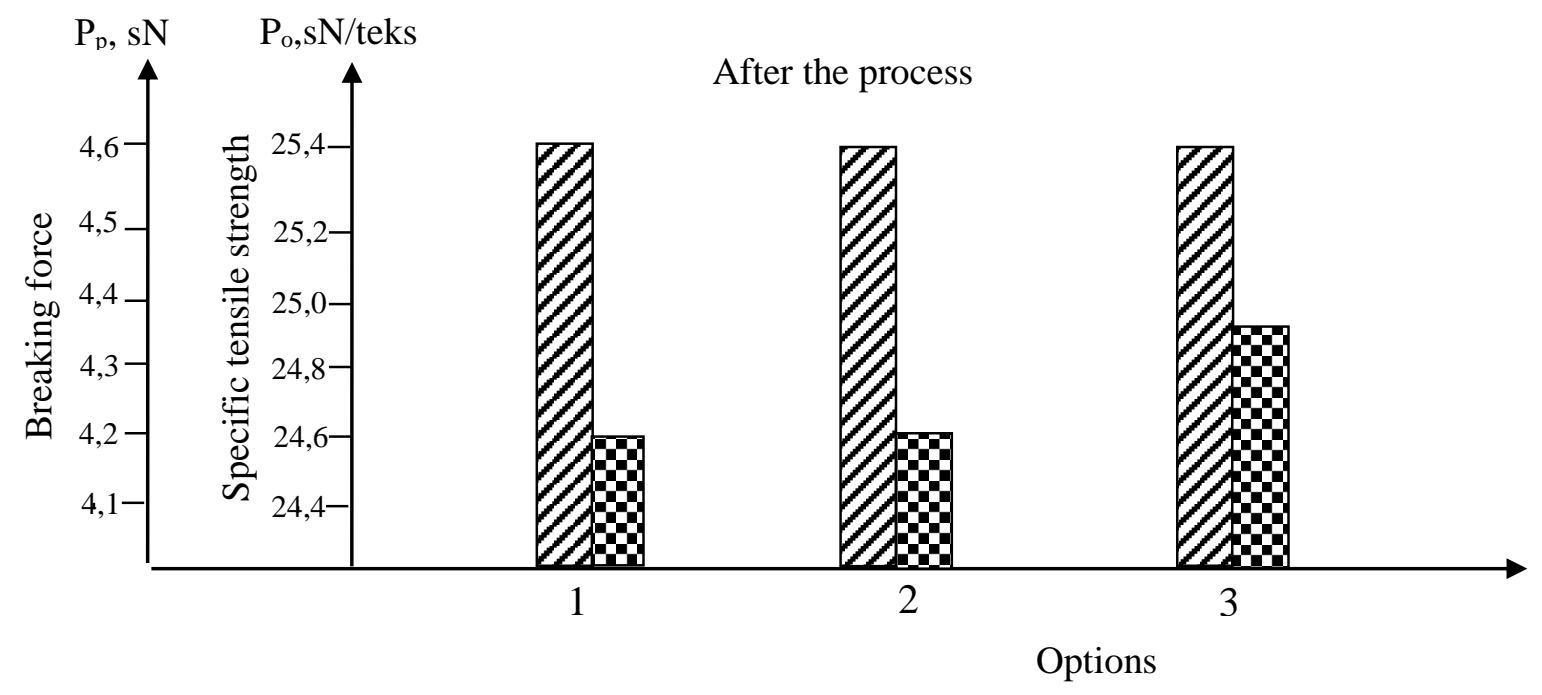

$\boldsymbol{\square}$-breaking force;
-specific tensile strength.

Figure 2. Influence of technological processes on fiber tensile strength and specific tensile strength

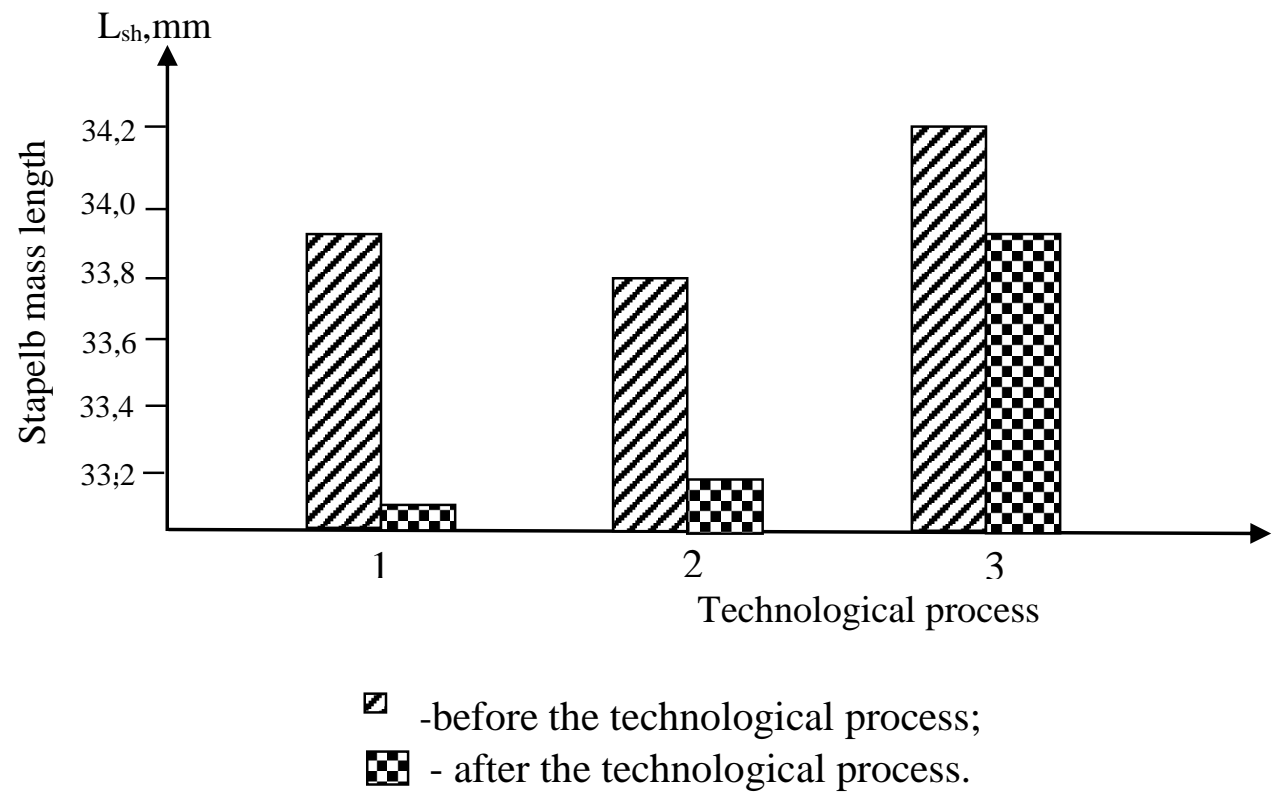

Figure 3. The effect of technological processes on the staple mass length of the fiber. 
Analyzing the research work, the tensile strength of the fiber obtained under the variant 1 before the technological process was $4.6 \mathrm{sN}$, the specific tensile strength was $25.0 \mathrm{sN}$ / tex, the staple mass length was $33.9 \mathrm{~mm}$. The tensile strength of the obtained fiber is $4.6 \mathrm{sN}$, the specific tensile strength is $24.6 \mathrm{sN} /$ tex, the staple mass length is $32.5 \mathrm{~mm}$, the tensile strength of the fiber obtained under option 2 before the technological process is $4.6 \mathrm{sN}$, specific tensile strength $25.1 \mathrm{sN} /$ tex, staple mass length $33.8 \mathrm{~mm}$, the tensile strength of the fiber obtained from the technological process according to option 2 is $4.6 \mathrm{sN}$, specific tensile strength $24.6 \mathrm{sN} /$ tex, staple mass length $32.8 \mathrm{~mm}$, the tensile strength of the fiber obtained according to option 3 before the technological process is $4.6 \mathrm{sN}$, the specific tensile strength is $25.4 \mathrm{sN} / \mathrm{tex}$, the staple mass length is $34.2 \mathrm{~mm}$, the technological process 3 The breaking strength of the obtained fiber is $4.6 \mathrm{sN}$, the specific breaking strength is 24.9 $\mathrm{sN}$./tex, the staple mass length was $33.9 \mathrm{~mm}$.

The analysis of the results shows that the more technological processes cotton is processed in, the lower the specific tensile strength and staple mass length of the fiber.

The results of the analysis showed that due to the reduction of the sequence of the technological process, the total amount of defect or waste in the fiber content decreased from $13.6 \%$ to $20.3 \%$, the amount of hull fiber from $54.1 \%$ to $53.3 \%$, the amount of crushed or injured seeds From $14.0 \%$ to $19.4 \%$, the amount of nodules increased from $33.3 \%$ to $50.0 \%$, the amount of impurities decreased from $54.3 \%$ to $53.3 \%$.

\section{CONCLUSION}

Analyzing the test results obtained on the physical and mechanical properties of the fiber, the specific tensile strength of the fiber obtained before the technological process for option 1 is $0.4 \mathrm{sN} /$ tex, and the length of the staple mass is $1.4 \mathrm{~mm}$, before the technological process for option 2 the specific tensile strength of the obtained fiber is $0.5 \mathrm{sN} /$ tex and the staple mass length is $1.0 \mathrm{~mm}$, the specific tensile strength of the fiber obtained before the technological process according to option 3 is $0.5 \mathrm{sN} /$ tex, and the staple mass length is 0.3. decreased by $\mathrm{mm}$.

\section{REFERENCES}

1. Khamraeva, S. A., Yusupova, N. B., Atambaev, D. D. O., \& Hasanov, M. H. O. (2020). The Importance Of The Extension Tool In Reducing The Inequality Of Yarn. The American Journal of Engineering and Technology, 2(08), 39-44. https://doi.org/10.37547/tajet/Volumeo2ls sue08-05

2. Atambayev, D. D. O. (2020). Analysis Of Fibrous Wastes Generated During Spinning Of Cotton Fiber In The ReSpinning System. The American Journal of Engineering and Technology, 2(09), 86-90. https://www.usajournalshub.com/index.p hp/tajet/article/view/960

3. Dilmuhammad Davronbekogli Atambayev, Muhriddin Hakimjonogli Hasanov, Analysis of Fibrous Waste 
The American Journal of Applied sciences

(ISSN - 2689-0992)

Published: April 30, 2021 | Pages: 241-249

Generated in the Preparation

Departments of Spinning Mills and Cotton

Processing.

http://www.ijarset.com/volume-7-issue-

9.html\#

4. Korabayev Sh.A; Matismailov S.L; Yuldashev A.T., Atanbayev D.D. (2020) "Study Of Fiber Movement Outside The Crater Of Pnevmomechanical Spinning Machine", Solid State Technology. Vol. 63 : Iss. 6. Pages 3460-3466. http://www.solidstatetechnology.us/inde x.php/JSST/article/view/3473

5. Atambaev Dilmukhammad Davronbek ogli1, Olimjonov Dilshodbek Khasanboy ogli ACADEMICIA: An International Multidisciplinary Research Journal , Production of arkok (enlama) hair wool fabrics on modern flexible fabric knitting machine in textile ( 2294) Last page:(2299)https://www.indianjournals.c om/ijor.aspx?target=ijor:aca\&volume $=10 \&$ issue $=11 \&$ article $=367$

6. Jitendra P.S, Swedesh V. Woven Terry Fabrics, Woodhead Publishing Series in Textiles Volume Number: 184.

7. Kosimov, A. A., Bakhriddinova, S. F. K., \& Abdulazizov, S. A. O. (2020). Classification Of Terry Products Made Of Natural Fiber. The American Journal of Engineering and Technology, 2(11), 133-141. https://doi.org/10.37547/tajet/Volume02ls sue11-21

8. Karahan M. Experimental investigation of the effect of fabric construction on dynamic water absorption in terry fabrics. Fibres Text East Eur 2007;15(3):74-80.

9. А.Г. Севастьяновни “Методы и средства исследования

механико-технологических процессов текстильной и легкой промышленности".
10. Atanbayeb Dilmuhammad Каримов Р.К., Mirjamol Mirxojayev Mirkarimovich.,Ahtam Qosimov Akramovich, “Анализы качество хлопкового волокна и приборы на ТестирОВании", НАУЧНО-ТЕХНИЧЕСКИЙ ЖУРНАЛ ФерПИ, 2019/3, 162-163.

11. Kosimov Ahtam Akramovich Abdullayev Ulugbek To'lanboyevich, Mirjamol Mirxojayev Mirkarimovich, Oqboyev Alisher Rasuljanovich, Анализ производство ткань для дублирин из отходов волокнистых материалов гребнечёсяльного системы, НАУЧНОТЕХНИЧЕСКИЙ ЖУРНАЛ ФерПИ, 2018/12, спец. вып. № 3, 42-46.

12. Башриддинова Ш Қосимов Ахтам Акрамович, Мирхожаев М, Оқбоев А, “Методы определения капиллярностьи текстильных тканьей", НАУЧНОТЕХНИЧЕСКИЙ ЖУРНАЛ ФерПИ, 2018/12, спец. вып. № 3, 166-169.

13. Башриддинова ш Қосимов Ахтам Акрамович, Маматханова О, “Тўқимачилик материалларини капиллиярлигини аниқлаш”, Наманган Халқаро конференция тўплами 2018 йил, 2018/6, 223.

14. Mirkhojayev Mirjamol Mirkarimovich; Ahmadjanov Sukhrob Bakhtiyor ogli "The study of physical and mechanical properties of different fabrics for suit gauze" ACADEMICIA An International Multidisciplinary Research Journal (Double Blind Refereed \& Peer Reviewed Journal) №2 November 2020 Pages 10491055. https://saarj.com/wpcontent/uploads/ACADEMICIANOVEMBER-2020-FULL-JOURNAL.pdf

15. Mirkhojayev Mirjamol Mirkarimovich; Egashov Bahodir Abdumukhtor o'gli. "Analysis of determination of cotton field 
quality as aresult of changes in technological processe" SAARJ Journal on

Banking \&Insurance Research (SJBIR ) №9 November2020. Pages 38-44. https://saarj.com/sjbir_current-issue/

16. Mirkhojayev Mirjamol Mirkarimovich; Ergashov Jamshid Fakhridin ogli. "Analysis Of Tanda Yarn Fiber Quality Indicators In Cotton Yarn Hardened Fabric Production" The American Journal Of Engineering And Technology №2 September 2020. Pages 82

https://usajournalshub.com/index.php/taj et/article/view/959

17. Mirkhojayev Mirjamol Mirkarimovich. "Method Of Assessing The Bending Resistance Of Yarns In Suit Folding Fabrics". The American Journal of Engineering And Technology №2 September 2020 Pages 98-100. https://www.usajournalshub.com/index.p hp/tajet/article/view/962

18. Mirkhojayev Mirjamol Mirkarimovich; Iskandarov Orifkhon Fozilkhon o'gli "The Study Of The Fineness Of Textile Materials In Small Manufacturing Enterprises" The American Journal Of Engineering And Technology №2 November 2020. Pages 174-178

https://usajournalshub.com/index.php/taj et/article/view/1533

19. Максудов, Н. Б., Нигматова, Ф. У., Юлдашев, Ж. К., \& Абдувалиев, Р. Р. (2018). Анализ деформационных свойств высокоэластичных трикотажных полотен для проектирования спортивной одежды. Universum: технические науки, (9 (54)).

20. Yuldashev, J. Q., \& Bobojanov, H. T. (2020). Study Of The Influence Of The
Parameters Of The Sampling Zone On The Condition Of The Capture Of Fibers By The

Drum Teeth. The American Journal of Engineering and Technology, 2(08), 75-78. https://doi.org/10.37547/tajet/Volume02ls sueo8-11

21. Bobojonov, H. T., Yusupov, A. A., Yuldashev, J. Q., \& Sadikov, M. R. (2020). Influence of deformation properties of yarn on the quality of knitted fabric. Test Engineering and Management, 2950229513.

22. Оқбоев А.Р. Тикув-трикотаж саноати корхоналарининг портфель стратегияларидан фойдаланиш имкониятлари. // Иқтисодиёт ва инновацион технологиялар илмий электрон журнали. 2021 йил 1-сон. (08.00.00; №10).

23. Оқбоев А.Р. Тикув-трикотаж корхоналарида брендинг стратегиясини ишлаб чиқиш методологияси. // Бизнесэксперт журнали. 2020 йил 7-сон. 115-119 бетлар (08.00.00; №3).

24. Оқбоев А.Р. Тикув-трикотаж корхоналарида бренд рақобатбардошлигини бошқариш. // Иқтисодиёт ва таълим. 2020 йил 6-сон. 132-137 бетлар (08.00.00; №11).

25. Okboyev A.R. Social Network Marketing and Its Development // International Journal of Research in Management \& Business Studies (IJRMBS 2020). Vol. 7 Issue 3 July - Sept. 2020. Impact Factor: SJIFNo23 2016=7.05. ISSN: 2348-6503 (Online) ISSN : 2348-893X (Print) pp. 3842. 
26. Okboyev A.R., O.J.Ashurkulov Directions for the introduction of an integrated quality management system to increase the competitiveness of light industry enterprises // South Asian Journal of Marketing \& Management Research (SAJMMR). Vol.10, Issue 11, November 2020 Impact Factor: SJIFNo23 2020=7.11. pp. 107-10. 